\title{
Thermal effects on heterotrophic processes in a coastal ecosystem adjacent to a nuclear power plant
}

\author{
Fuh-Kwo Shiah ${ }^{1,2, *}$, Tsong-Han $\mathrm{Wu}^{3}$, Kuo-Yuan $\mathrm{Li}^{3}$, Shui-Ji Kao ${ }^{2}$, Yu-Feng Tseng ${ }^{3}$, \\ Jia-Lu Chung ${ }^{3}$, Sen Jan ${ }^{4}$
}

${ }^{1}$ Institute of Marine Environmental Chemistry and Ecology, National Taiwan Ocean University, Keelung, Taiwan

${ }^{2}$ Research Center for Environment Changes, Academia Sinica, NanKang, Taipei, Taiwan

${ }^{3}$ Institute of Oceanography, National Taiwan University, Taipei, Taiwan

${ }^{4}$ Institute of Hydrological Sciences, National Central University, Chung-Li, Taiwan

\begin{abstract}
During the period October 2001 to August 2002, weekly sampling on bacterial respiration (BR, 3 to $22 \mathrm{mg} \mathrm{C} \mathrm{m}^{-3} \mathrm{~d}^{-1}$ ) and microplankton community respiration (CR, size fraction $<300 \mu \mathrm{m}, 2$ to $90 \mathrm{mg} \mathrm{C} \mathrm{m}^{-3} \mathrm{~d}^{-1}$ ) was conducted in the inlet and outlet of Taiwan Nuclear Power Plant II (TNP-II). In addition, 3 transect surveys were conducted across the warm plume outside the TNP-II outlet. All measurements except dissolved organic carbon (DOC, 18 to $45 \mathrm{~g} \mathrm{C} \mathrm{m}^{-3}$ ) varied seasonally and spatially with temperature. On average, BR constituted $41 \%$ of the total CR. The BR/CR ratios were negatively correlated with $\mathrm{CR}$, the first observation of this trend that we are aware of. The positive temperature responses of rate and/or biomass-normalized rate parameters indicated a very low probability of bottom-up (substrate supply) control on the growth of heterotrophic organisms in these systems. The $Q_{10}$ (i.e. the increase of rate with a temperature increase of $10^{\circ} \mathrm{C}$ ) values for $\mathrm{BR}, \mathrm{CR}$, biomass-normalized bacterial respiration ( 0.07 to $\left.1.31 \mathrm{~d}^{-1}\right)$ and particulate organic carbon-normalized CR ( 0.04 to $\left.0.52 \mathrm{~d}^{-1}\right)$ ranged from 1.3 to 3.7 . Similar Arrhenius expressions of heterotrophic processes in the field surveys and short-term temperature-manipulation experiments showed that, in this high DOC system, most planktoners were eurythermal and that their respiration increased with temperature up to $>35^{\circ} \mathrm{C}$. Such a phenomenon might be related to a temperature-substrate interaction.
\end{abstract}

KEY WORDS: Bacterial production $\cdot$ Community respiration $\cdot$ Bottom-up control $\cdot Q_{10} \cdot$ Trophic status

\section{INTRODUCTION}

Studies of planktonic tropho-dynamics from an ecosystem perspective have been very popular since the 1980s. Research results derived from natural ecosystems have greatly increased our understanding of biogeochemical processes occurring within and between systems. Community respiration (CR) and primary production (PP) are the 2 opposed key processes controlling organic material cycling within any ecosystem. From a perspective of biogenic organic carbon cycling, PP represents the rate of organic carbon formation by primary producers, while $\mathrm{CR}$ is the sum of organic carbon consumption conducted by all living organisms, including the primary producers themselves. However, as noted in several studies, little research has been done on CR in comparison with that done on PP (Rivkin \& Legendre 2001, Smith \& Kemp 2003).

Through increasing anthropogenic activities, many coastal systems have been experiencing instances of human disturbance. One of the environmental issues associated with the operation of (nuclear) power plants is the potential thermal stress to aquatic organisms living nearby. In Taiwan, thermal effluents from nuclear power plants have resulted in 'malformed' fish (Hung et al. 1998) and coral bleaching (Dai 1999). Related studies of thermal stress on planktonic activities have been conducted elsewhere, but with limited measurements. For example, Servais \& Billen (1989) studied the thermal effects on primary and bacterial production, 
and Choi et al. (2002) worked on the influence of thermal stress on the activity of heterotrophic bacterioplankton and nanoflagellates. The system characteristic CR was not analyzed in either study. Moreover, these 2 (and most relevant) studies were conducted in temperate regions, with maximal temperatures $<30^{\circ} \mathrm{C}$. The responses of planktonic activity to a thermal plume (temperatures $>30^{\circ} \mathrm{C}$ ) remain to be explored. A study of the behavior of various plankton in a highly disturbed system might serve as a good reference point for checking many current notions regarding carbon cycling and planktonic tropho-dynamics.

Within the water column, microplankton (size $<300 \mu \mathrm{m}$ ) has been suggested to be a more important contributor to the total CR than larger (size $>300 \mu \mathrm{m}$ ) organisms (Pomeroy 1974, Sampou \& Kemp 1994, Smith \& Kemp 2001). Of organisms $<300 \mu \mathrm{m}$, heterotrophic bacteria have been considered to be the major consumers of $\mathrm{O}_{2}$, due to their larger surface area to volume ratio. Bacterial respiration (BR) alone has been shown to contribute as much as $>70 \%$ to the total microplankton CR (Toolan 2001). High BR values have been suggested to be the major factor determining the heterotrophic status of many coastal and even oceanic ecosystems (Smith \& Hollibaugh 1993, del Giorgio et al. 1997, Duarte \& Agusti 1998).

In eutrophic ecosystems, many heterotrophic processes have been considered to be driven primarily by temperature on various temporal and spatial scales (Lomas et al. 2002). It should be noted that most of our knowledge on thermal responses is based on field surveys of systems, of which the maximal annual temperature seldom exceeds $30^{\circ} \mathrm{C}$. For coastal areas, 2 increasing trends seem to be inevitable. One is global warming, and the other is the upsurge of inorganic and organic loadings due to anthropogenic activities (Bauer \& Druffel 1998). This study is aimed to depict the controlling mechanisms of the seasonal variation of $\mathrm{BR}$ and $\mathrm{CR}$ in the inlet $\left(19\right.$ to $\left.29^{\circ} \mathrm{C}\right)$, outlet $\left(29\right.$ to $\left.39^{\circ} \mathrm{C}\right)$ and the warm plume outside the outlet $\left(21\right.$ to $\left.37^{\circ} \mathrm{C}\right)$ of a nuclear power plant, where dissolved organic carbon concentrations are high. A concomitant study of the seasonal changes of $\mathrm{CR}$ and $\mathrm{BR}$ in a eutrophic coastal ecosystem with distinct annual temperature regimes (see below) may provide valuable information for our understanding of carbon cycling today and in the future.

\section{MATERIALS AND METHODS}

Study site and sampling. Weekly samplings were conducted at the inlet ( 2 stations) and outlet (1 station) of Taiwan Nuclear Power Plant II (TNP-II, Fig. 1). A total of 44 weekly samples were carried out from October 2001 to August 2002. The 2 inlet stations were located inside the inlet, separated by a distance of $\sim 200 \mathrm{~m}$. Surface-water samples were taken by pre-acid-washed $(0.1 \mathrm{~N} \mathrm{HCl})$ buckets and then transferred into $20 \mathrm{l}$ opaque polycarbonate (PC) carboys. Temperature and salinity were recorded with a SC82 portable recorder (Yokogawa). It took $\sim 1 \mathrm{~h}$ to transport the storage bottles to the laboratory for further analysis. In order to explore spatial variation, transect surveys were conducted in November 2001, May 2002 and June 2002, with 7 stations (Stns T1 to T7, Fig. 1) on each transect, which encompassed the 'warm water plume' outside the outlet. All 3 studies were conducted during the daytime within the same tidal amplitude (i.e. the ebb tide) based on the tidal table provided by the Central Weather Bureau, Taiwan. Temperatures were recorded with a SeaBird CTD (SBE 9/11+). Surface waters were sampled with $5.0 \mathrm{l}$ Go-Flo bottles stored in 201 opaque PC carboys.

Inorganic nutrients and chlorophyll a. A custommade flow injection analyzer with a detection limit of $0.15 \mu \mathrm{M}$ was used for nitrate $\left(\mathrm{NO}_{3}\right)$ analysis (Gong et al. 1995). Chlorophyll a (chl a) concentrations were measured by in vitro fluorometery (Turner Design 10AU-005) following acetone extraction (Parsons et al. 1984).

Particulate and dissolved organic carbon concentrations. Samples for particulate organic carbon (POC) were filtered through a Whatman $25 \mathrm{~mm}$ GF/F filter, wrapped in aluminum foil and then stored at $-4^{\circ} \mathrm{C}$. Both filters and aluminum foils were pre-combusted at

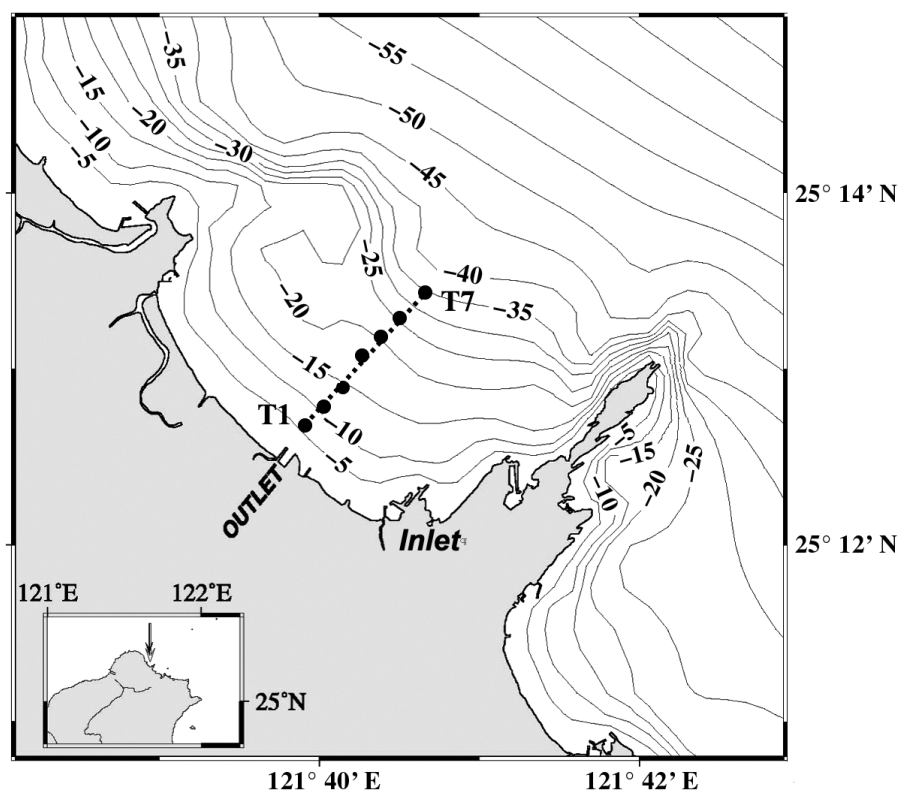

Fig. 1. Map of the study area showing sampling stations for the weekly (inlet and outlet) and transect (Stns T1 to T7) studies. Dashed line indicates bottom depth 
$550^{\circ} \mathrm{C}$ for $1 \mathrm{~h}$. After drying and acid-fuming, samples were measured by the combustion method (EMIA-510, Horiba). Samples for dissolved organic carbon (DOC) measurement were filled into pre-combusted $40 \mathrm{ml}$ vials. After the addition of several drops of $80 \% \mathrm{H}_{3} \mathrm{PO}_{4}$, vials were sealed with pre-combusted aluminum foil and screw caps with Teflon-coated septa. Before analysis, samples were acidified with $80 \% \mathrm{H}_{3} \mathrm{PO}_{4}$ and sparged with $\mathrm{CO}_{2}$-free $\mathrm{O}_{2}$ at a flow rate of $350 \mathrm{ml} \mathrm{min}{ }^{-1}$ for at least $10 \mathrm{~min}$. Samples were analyzed by the hightemperature catalytic oxidation method with a TOC 5000 (Shimadzu). All samples were blank (20 to $25 \mu \mathrm{M}$ ) corrected and double checked with the measurements of the deep-water $(\sim 3000 \mathrm{~m})$ samples taken from the South China Sea $(\mathrm{DOC} \times 50 \mu \mathrm{M})$.

Bacterial biomass, production and respiration rate. Bacterial abundance (BA) was estimated by the Acridine Orange Direct Count method (Hobbie et al. 1977) with an epi-fluorescence microscope (Axioplan 2, Zeiss). Bacterial activity was measured by ${ }^{3} \mathrm{H}$-thymidine incorporation (Fuhrman \& Azam 1982). Bacterial biomass (BB) and production (BP) in $\mathrm{C}$ units were derived with a thymidine and a carbon conversion factor of $1.8 \times 10^{18}$ cells mol $^{-1}$ (Ducklow \& Carlson 1992) and $2 \times 10^{-14} \mathrm{~g} \mathrm{C} \mathrm{cell}^{-1}$ (Lancelot \& Billen 1984), respectively. For details of the ${ }^{3} \mathrm{H}$-thymidine measurement, see Shiah et al. (2003). In a succeeding study, F.-K. Shiah \& C.-C. Lai (unpubl. data, September 2002 to May 2004) used the $\mathrm{O}_{2}$ consumption method (see below) to estimate the bacterial respiration rate (BR) in the $1.0 \mu \mathrm{m}$ filtrate. Their data indicated an empirical formula of: $\mathrm{BR}=1.36 \times \mathrm{BP}^{0.62}\left(\mathrm{n}=31, \mathrm{R}^{2}=0.95, \mathrm{p}<0.01\right)$ for the conversion of BP to BR.

Community respiration rate. Micro-plankton $\mathrm{CR}$ rates were measured by the decrease of $\mathrm{O}_{2}$ concentrations in dark incubation. In brief, $300 \mu \mathrm{m}$ mesh filtrates (macro zooplankton removed) were filled into triplicate opaque $21 \mathrm{PC}$ bottles. Incubation was performed at in situ temperature for 12 to $24 \mathrm{~h}$. Initial and final $\mathrm{O}_{2}$ concentrations were measured by the Shibala method (Pai et al. 1993). A molar ratio of $\mathrm{O}_{2}: \mathrm{CO}_{2}=138: 106$ (Redfield et al. 1963) was used to convert $\mathrm{O}_{2}$ into carbon units. Parallel comparisons between incubation in $21 \mathrm{PC}$ and $500 \mathrm{ml}$ DO (dissolved oxygen) bottles (triplicates for each incubation) were performed in the first $7 \mathrm{wk}$. No significant difference between these 2 types of incubation vessels ( $t$-test, $\mathrm{p}>0.5$ ) was found.

Temperature effects on community and bacterial respiration. We conducted 3 temperature manipulation experiments in December 2001, March 2002 and August 2002. Water samples taken from the inlet were pre-incubated in $1 \mathrm{l} \mathrm{PC}$ bottles for $1 \mathrm{~h}$ in 5 treatments (in triplicate), with temperatures ranging from 20 to $45^{\circ} \mathrm{C}$. CR and BR were measured after $12 \mathrm{~h}$ of incubation in the dark. POC concentrations for these 3 exper- iments were 102, 121 and $154 \mathrm{mg} \mathrm{C} \mathrm{m}^{-3}$, respectively. The BB values for these 3 experiments were 43.2, 42.1 and $44.2 \mathrm{mg} \mathrm{C} \mathrm{m}^{-3}$, respectively.

\section{RESULTS}

\section{The inlet system}

All measurements derived from the 2 inlet stations were quite similar. We used their averages to describe the seasonal variation. Temperature $(\mathrm{T})$ showed strong seasonal fluctuation (18 to $29^{\circ} \mathrm{C}$, Fig. 2A), with lower and higher values appearing in winter $\left(<22^{\circ} \mathrm{C}\right.$, midNovember to early March of the next year) and summer ( $>27^{\circ} \mathrm{C}$, early June to August), respectively. Salinity (18.7 to $35.4 \mathrm{psu}$, data not shown) values were low in autumn and spring, but higher in winter and summer. $\mathrm{NO}_{3}$ concentrations $(<0.2$ to $8.5 \mu \mathrm{M})$ showed a negative trend with $\mathrm{T}$ (Table 1 ). Chl a concentrations varied 20 -fold ( $<0.2$ to $3.1 \mathrm{mg} \mathrm{chl} \mathrm{m}^{-3}$, Fig. 2B), with higher values appearing in early November and midMay, indicating a possibility of autumn and spring blooms. Chl a values were positively and negatively correlated with $\mathrm{T}$ and $\mathrm{NO}_{3}$, respectively (Table 1). The seasonal pattern of POC (47 to $288 \mathrm{mg} \mathrm{C} \mathrm{m}^{-3}$, Fig. 2B) followed that of chl $a$, and its relationships with $\mathrm{T}$ and $\mathrm{NO}_{3}$ were quite similar to those of chl a (Table 1). Concentrations of DOC (18 to $45 \mathrm{~g} \mathrm{C} \mathrm{m}^{-3}$, Fig. 2C) were very high throughout the investigation period, with an average of $29.5 \pm 2.4 \mathrm{~g} \mathrm{C} \mathrm{m}^{-3}$. DOC showed no correlation with any other variables (Table 1 ).

BR varied $\sim 10$-fold, ranging from 3.2 to $21.5 \mathrm{mg} \mathrm{C}$ $\mathrm{m}^{-3} \mathrm{~d}^{-1}$ (Fig. 2C), and were positively correlated with $\mathrm{T}$ and POC (Table 1). BB (30 to $75 \mathrm{mg} \mathrm{C} \mathrm{m}^{-3}$, Fig. 2D) did not vary much, and showed no relationship with other measurements (Table 1). However, with the 2 exceptions of high $\mathrm{BB}$ ( $>60 \mathrm{mg} \mathrm{C} \mathrm{m}^{-3}$ ) recorded in mid-July 2002 , there was a trend indicating that lower BB values were not found in the warm season $(\mathrm{r}=-0.71, \mathrm{n}=82$, $\mathrm{p}<0.01)$. BB-normalized respiration rate (NBR, 0.07 to $0.38 \mathrm{~d}^{-1}$, Fig. 2D) varied $\sim 5$-fold. NBR changed positively with $\mathrm{T}$ and negatively with $\mathrm{NO}_{3}$ (Table 1). CR values varied $>20$-fold (2.5 to $74.6 \mathrm{mg} \mathrm{C} \mathrm{m}^{-3} \mathrm{~d}^{-1}$, Fig. 2E), and were positively correlated with all measured variables except $\mathrm{NO}_{3}$ and DOC (Table 1). The ratios of BR/CR (Fig. 2E, 0.14 to 1.37 ) varied $>10$-fold, with an average of $0.41 \pm 0.25$. Note that only 2 out of $39 \mathrm{BR} / \mathrm{CR}$ data were $>1.0$. The BR/CR ratios were negatively correlated with POC and CR (Table 1). Overall, with the exception of DOC, measurements recorded at the inlet showed seasonal fluctuation, with higher values appearing in summer, while $\mathrm{NO}_{3}$ concentrations behaved negatively with regard to seasonal temperature. 

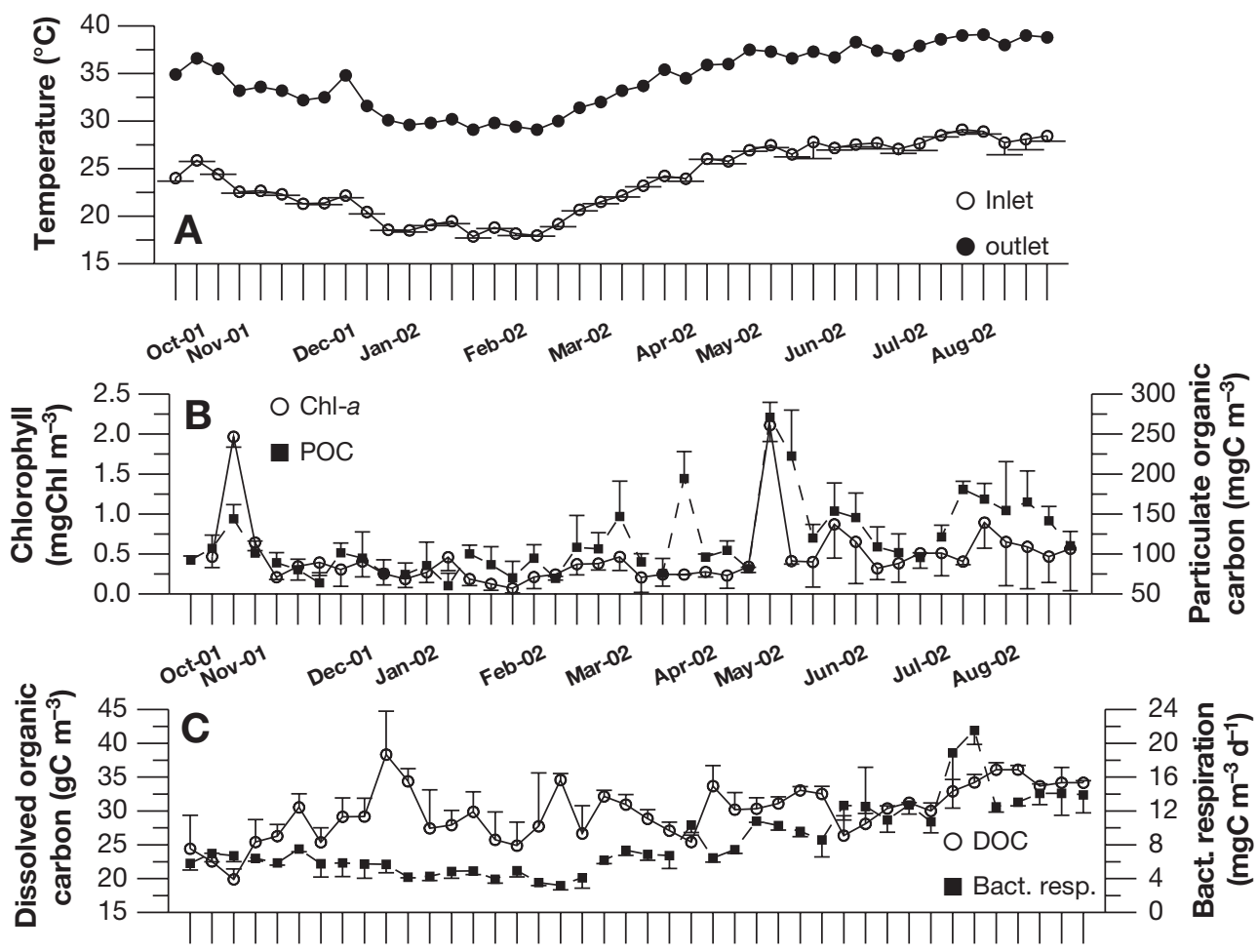

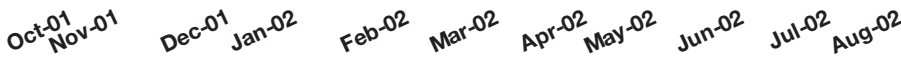
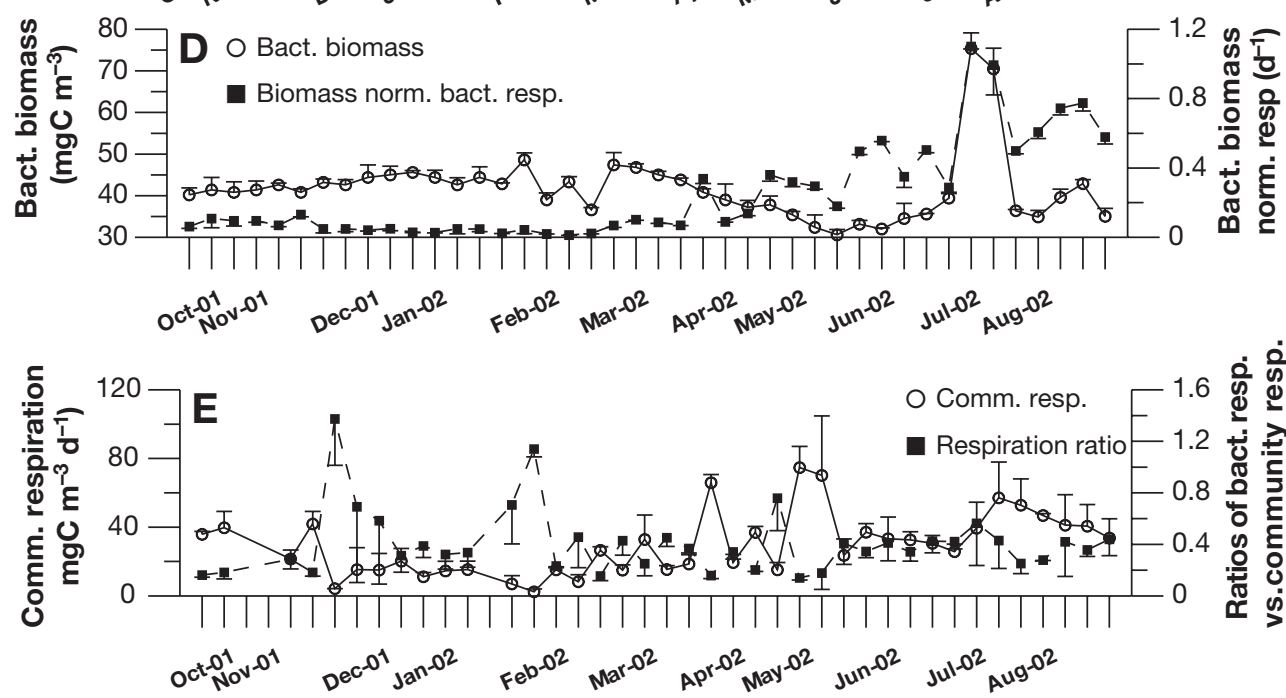

Fig. 2. Weekly changes of the inlet measurements from October 2001 to August 2002: (A) temperature, (B) chlorophyll a and particulate organic carbon, (C) dissolved organic carbon and bacterial respiration, (D) bacterial biomass and bacterial-biomassnormalized respiration and (E) community respiration and the ratios of bacterial vs. community respiration. Vertical bars indicate standard deviations of the 2 inlet stations

\section{The outlet system}

Seasonal variations of measurements recorded at the outlet were quite similar to their counterparts at the inlet (correlation coefficient, $r=+0.64$ to +0.99 , $\mathrm{p}<0.01, \mathrm{n}=36$ to 44 ), with several notable distinctions. Temperatures $\left(28\right.$ to $39^{\circ} \mathrm{C}$, Fig. $\left.2 \mathrm{~A}\right)$ at the outlet were ca. $10^{\circ} \mathrm{C}$ higher than those at the inlet. Chl a concentrations $\left(<0.15\right.$ to $2.3 \mathrm{mg} \mathrm{chl} \mathrm{m}^{-3}$ ), BR (4 to $22 \mathrm{mg} \mathrm{C} \mathrm{m} \mathrm{C}^{-3}$ ) and BB (6 to $52 \mathrm{mg} \mathrm{C} \mathrm{m}^{-3}$ ) at the outlet were 40,77 and $27 \%$ those at the inlet, respectively. On the other hand, values of NBR at the outlet $\left(0.3\right.$ to $\left.1.3 \mathrm{~d}^{-1}\right)$ were about 3 -fold higher than those at the inlet. 
Table 1. Correlation matrix and ranges of measured variables for the inlet stations in the weekly study ( $\mathrm{T}$ : temperature; $\mathrm{NO}_{3}$ : nitrate concentrations; chl a: chlorophyll concentrations; POC: particulate organic carbon concentrations; DOC: dissolved organic carbon concentrations; BB: bacterial biomass; BR: bacterial respiration; NBR: bacterial-biomass-normalized respiration; CR: microplankton community respiration; NCR: POC-normalized community respiration; BR/CR: the ratios of bacterial respira-

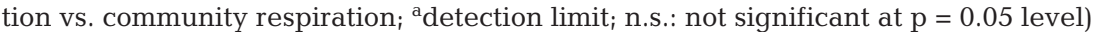

\begin{tabular}{|c|c|c|c|c|c|c|c|c|c|c|c|}
\hline Items & Ranges, units & $\mathrm{T}$ & $\mathrm{NO}_{3}$ & Chl $a$ & POC & DOC & $\mathrm{BB}$ & $\mathrm{BR}$ & NBR & $\mathrm{CR}$ & NCR \\
\hline $\mathrm{T}$ & $17.9-29.1^{\circ} \mathrm{C}$ & & & & & & & & & & \\
\hline $\mathrm{NO}_{3}$ & $<0.15^{\mathrm{a}}-8.5 \mu \mathrm{M}$ & -0.90 & & & & & & & & & \\
\hline Chl a & $0.15^{\mathrm{a}}-2.3 \mathrm{mg} \mathrm{chl} \mathrm{m} \mathrm{m}^{-3}$ & +0.42 & -0.42 & & & & & & & & \\
\hline POC & $47-288 \mathrm{mg} \mathrm{C} \mathrm{m}^{-3}$ & +0.44 & -0.44 & +0.57 & & & & & & & \\
\hline DOC & $18-45 \mathrm{~g} \mathrm{C} \mathrm{m}^{-3}$ & n.s. & n.s. & n.s. & n.s. & & & & & & \\
\hline BB & $31-75 \mathrm{mg} \mathrm{C} \mathrm{m}{ }^{-3}$ & n.s. & n.s. & n.s. & n.s. & n.s. & & & & & \\
\hline $\mathrm{BR}$ & $3-22 \mathrm{mg} \mathrm{C} \mathrm{m}^{-3} \mathrm{~d}^{-1}$ & +0.85 & -0.80 & n.s. & +0.61 & n.s. & - & & & & \\
\hline NBR & $0.07-0.38 \mathrm{~d}^{-1}$ & +0.87 & -0.75 & n.s. & n.s. & n.s. & - & & & & \\
\hline $\mathrm{CR}$ & $2-75 \mathrm{mg} \mathrm{C} \mathrm{m}^{-3} \mathrm{~d}^{-1}$ & +0.63 & -0.55 & +0.49 & +0.82 & n.s. & - & +0.64 & +0.59 & & \\
\hline NCR & $0.13-0.52 \mathrm{~d}^{-1}$ & +0.58 & -0.48 & & & & & & & & \\
\hline BR/CR & $0.14-1.37$ & n.s. & n.s. & n.s. & -0.41 & n.s. & - & n.s. & n.s. & -0.58 & \\
\hline
\end{tabular}

\section{Transect studies}

Most measurements of the 3 transect studies showed strong spatial traits. The November 2001 study is used as an example here. The highest water temperatures were always recorded at T1, which was located $\sim 500 \mathrm{~m}$ outside the outlet, temperatures then decreased seaward (Fig. 3A). The temperature difference between Stns $\mathrm{T} 1$ and $\mathrm{T} 7$ was about $8^{\circ} \mathrm{C}$. Concentrations of $\mathrm{NO}_{3}$ were high (5.1 to $5.6 \mu \mathrm{M}$, Fig. 3A) in November 2001. $\mathrm{NO}_{3}$ concentrations were lower $(<2.0 \mu \mathrm{M}$, Fig. 3A) in May 2002 and June 2002; there were no distinct spatial patterns of $\mathrm{NO}_{3}$ in these 2 surveys. Chl a concentrations ( $<0.2$ to $0.64 \mathrm{mg} \mathrm{chl} \mathrm{m}^{-3}$, Fig. 3B) increased seaward in all 3 surveys. Spatial patterns of chl a in November 2001 and May 2002 were quite similar, with

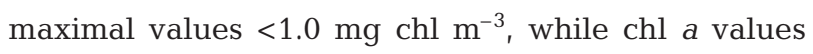
recorded in June 2002 at Stns T6 and T7 (>1.25 mg chl $\mathrm{m}^{-3}$ ) were higher than those of the 2 previous surveys and increased dramatically seaward. POC (66 to $115 \mathrm{mg} \mathrm{C} \mathrm{m}{ }^{-3}$, Fig. 3B) increased seaward in all 3 surveys.

DOC measurements varied between 23 and $34 \mathrm{~g} \mathrm{C}$ $\mathrm{m}^{-3}$, but showed no spatial patterns. Lower DOC concentrations (23 to $29 \mathrm{~g} \mathrm{C} \mathrm{m}^{-3}$, Fig. 3C) were recorded in November 2001. BR in November 2001 (Fig. 3C) and May 2002 were low (4 to $9 \mathrm{mg} \mathrm{C} \mathrm{m}^{-3} \mathrm{~d}^{-1}$ ) and varied insignificantly among stations. In June, BR (10 to $20 \mathrm{mg}$ $\mathrm{C} \mathrm{m}^{-3} \mathrm{~d}^{-1}$ ) values were high, and increased seaward by 2-fold when compared with the 2 previous studies. BB (11 to $48 \mathrm{mg} \mathrm{C} \mathrm{m}^{-3}$, Fig. 3D) in all 3 surveys increased seaward; however, NBR (0.14 to $0.86 \mathrm{~d}^{-1}$, Fig. 3D)
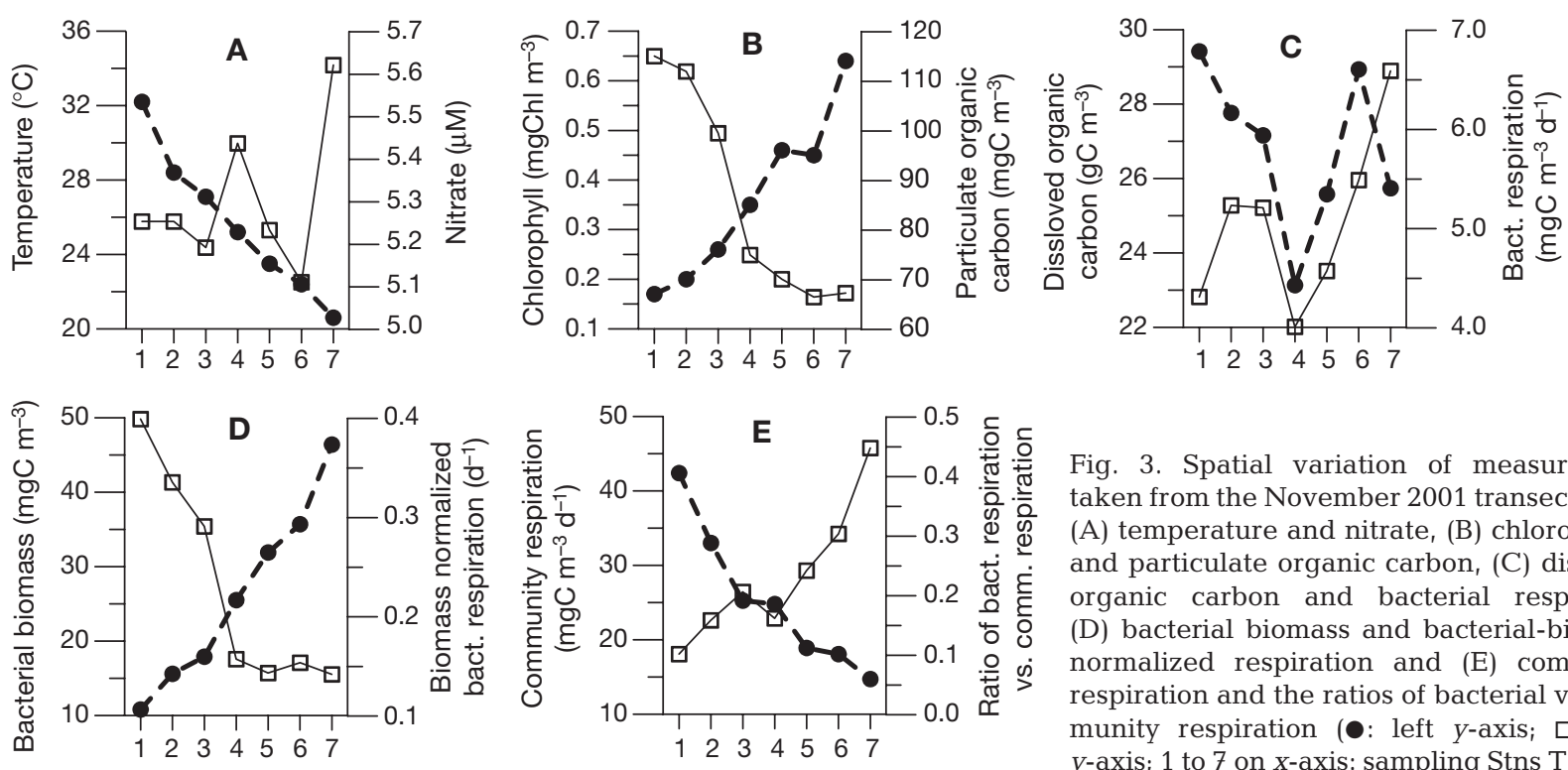

Fig. 3. Spatial variation of measurements taken from the November 2001 transect study: (A) temperature and nitrate, (B) chlorophyll $a$ and particulate organic carbon, $(\mathrm{C})$ dissolved organic carbon and bacterial respiration, (D) bacterial biomass and bacterial-biomassnormalized respiration and (E) community respiration and the ratios of bacterial vs. community respiration ( $\bullet$ : left $y$-axis; $\square$ : right $y$-axis; 1 to 7 on $x$-axis: sampling Stns T1 to T7) 
showed inverse trends with BB. CR data (13 to $68 \mathrm{mg} \mathrm{C}$ $\mathrm{m}^{-3} \mathrm{~d}^{-1}$ ) derived from the 3 studies all decreased seaward (Fig. 3E). The ratios of BR/CR (0.10 to 0.61, Fig. 3E) increased seaward by 6 -fold, with higher values appearing in June 2002.

Table 2 indicates the correlations among measured variables for the November 2001 study. The correlation matrices for the other 2 surveys were similar to that of the November 2001 study (data not shown). Note that within each survey, besides physiological effects on various measurements, the temperature pattern also indicated spatial variation and the magnitude of mixing between the background seawaters and the warm effluents from the outlet. $\mathrm{NO}_{3}$ and DOC showed no correlation with any other measurements. Biomass variables, including chl $a$ and $\mathrm{BB}$, changed negatively with temperature. NBR, CR, NCR and POC were all positively correlated with temperature. The only exception was BR, which showed no correlation with temperature.

\section{Short-term temperature effects on bacterial and community respiration rates}

In the 3 temperature-manipulation experiments, NCR and NBR followed an Arrhenius expression. That is, these rate parameters increased with rising temperature up to $>35^{\circ} \mathrm{C}$, and then decreased significantly at $45^{\circ} \mathrm{C}$ (Fig. 4A,B). Temperature responses of CR and BR were the same, but are not shown. The ratios of BR/CR showed a decreasing trend when temperature rose from 20 to $30^{\circ} \mathrm{C}$; however, this trend became irregular at temperatures $>30^{\circ} \mathrm{C}$ (Fig. $4 \mathrm{C}$ ). Within the temperature range of 20 to $35^{\circ} \mathrm{C}$, the $Q_{10}$ (the increase of rate with a temperature increase of $10^{\circ} \mathrm{C}$ ) values of $\mathrm{CR}$ and $\mathrm{BR}$ varied between 2.7 and 3.3. The temperature responses of NCR and NBR also showed the same trends (Table 3).
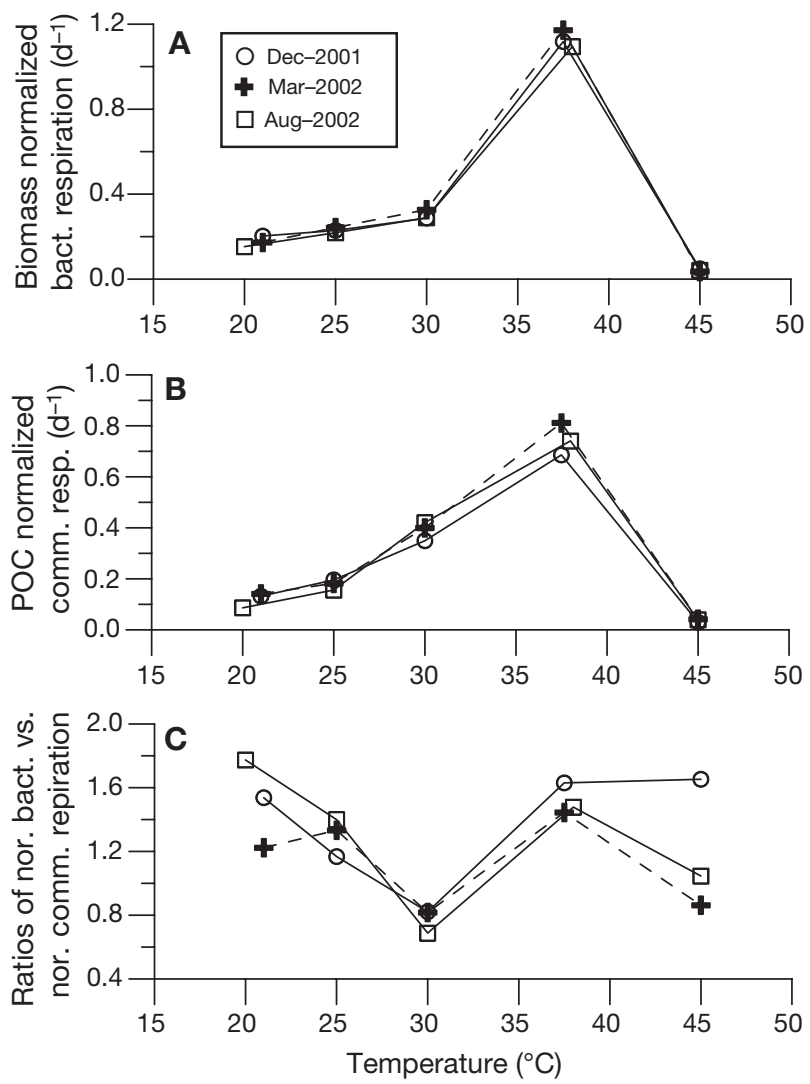

Fig. 4. Temperature effects on: (A) bacterial-biomass-normalized respiration, (B) POC-normalized community respiration and (C) the ratios of bacterial vs. community respiration. Standard deviations of triplicate incubations are too small to be shown

\section{Seasonal and spatial temperature responses of bacterial and community respiration}

The rate measurements for heterotrophic processes were all positively correlated with temperature exponentially (Table 3 ). The only exception was the BR of

Table 2. Correlation matrix and ranges of measured variables for the November 2001 study (n.s.: not significant at $\mathrm{p}=0.05$ level; ${ }^{a}$ detection limit; other abbreviations: see Table 1)

\begin{tabular}{|c|c|c|c|c|c|c|c|c|c|c|c|}
\hline Items & Ranges, units & $\mathrm{T}$ & $\mathrm{NO}_{3}$ & Chl a & POC & DOC & $\mathrm{BB}$ & $\mathrm{BR}$ & NBR & CR & NCR \\
\hline $\mathrm{T}$ & $21-32^{\circ} \mathrm{C}$ & & & & & & & & & & \\
\hline $\mathrm{NO}_{3}$ & $5.2-5.6 \mu \mathrm{M}$ & n.s. & & & & & & & & & \\
\hline Chl a & $0.2^{\mathrm{a}}-0.64 \mathrm{mg} \mathrm{chl} \mathrm{m}^{-3}$ & -0.94 & n.s. & & & & & & & & \\
\hline POC & $67-115 \mathrm{mg} \mathrm{C} \mathrm{m}^{-3}$ & +0.93 & n.s. & -0.90 & & & & & & & \\
\hline DOC & $23-29 \mathrm{~g} \mathrm{C} \mathrm{m}^{-3}$ & n.s. & n.s. & n.s. & n.s. & & & & & & \\
\hline $\mathrm{BB}$ & $11-46 \mathrm{mg} \mathrm{C} \mathrm{m}^{-3}$ & -0.95 & n.s. & +0.99 & -0.92 & n.s. & & & & & \\
\hline $\mathrm{BR}$ & $4.3-6.6 \mathrm{mg} \mathrm{C} \mathrm{m}^{-3} \mathrm{~d}^{-1}$ & n.s. & n.s. & n.s. & n.s. & n.s. & - & & & & \\
\hline NBR & $0.14-0.42 \mathrm{~d}^{-1}$ & +0.89 & n.s. & -0.86 & +0.98 & n.s. & - & - & & & \\
\hline $\mathrm{CR}$ & $15-42 \mathrm{mg} \mathrm{C} \mathrm{m}^{-3} \mathrm{~d}^{-1}$ & +0.98 & n.s. & -0.90 & +0.91 & n.s. & -0.91 & n.s. & +0.89 & & \\
\hline NCR & $0.22-0.37 \mathrm{~d}^{-1}$ & +0.78 & n.s. & -0.71 & n.s. & n.s. & n.s. & +0.82 & n.s. & - & \\
\hline $\mathrm{BR} / \mathrm{CR}$ & $0.10-0.45$ & -0.88 & n.s. & +0.93 & -0.73 & n.s. & +0.93 & +0.85 & n.s. & -0.84 & -0.85 \\
\hline
\end{tabular}


Table 3. List of the statistics for the linear regression of natural log-transformed bacterial respiration (BR), community respiration (CR), biomass-normalized BR (NBR) and POC-normalized CR (NCR) (n.s.: not significant at p = 0.05 level; SE: standard error; $\mathrm{n}$ : sampling size; $\mathrm{R}^{2}$ : coefficient of determination; $Q_{10}$ : the increase of rate with a temperature increase of $10^{\circ} \mathrm{C}$ ). Slopes with the same capital superscript letter are not considered different from each other at the $p=0.01$ level (ANCOVA)

\begin{tabular}{|c|c|c|c|c|c|c|c|}
\hline Data source & $\mathrm{T}$ range & Dependent variable & Intercept & Slope $( \pm \mathrm{SE})$ & $\mathrm{n}$ & $\mathrm{R}^{2}$ & $Q_{10}$ \\
\hline \multirow[t]{4}{*}{ Weekly inlet } & \multirow[t]{4}{*}{$18-30$} & Ln BR & -0.76 & $+0.12^{\mathrm{A}}( \pm 0.008)$ & 86 & 0.85 & 3.3 \\
\hline & & Ln CR & -0.33 & $+0.15^{\mathrm{B}}( \pm 0.022)$ & 78 & 0.53 & 4.5 \\
\hline & & Ln NBR & -4.93 & $+0.13^{\mathrm{C}}( \pm 0.007)$ & 86 & 0.90 & 3.7 \\
\hline & & Ln NCR & -3.36 & $+0.08^{\mathrm{D}}( \pm 0.017)$ & 78 & 0.35 & 2.2 \\
\hline \multirow[t]{4}{*}{ Weekly outlet } & \multirow[t]{4}{*}{$28-39$} & Ln BR & -1.83 & $+0.11^{\mathrm{A}}( \pm 0.009)$ & 43 & 0.78 & 3.0 \\
\hline & & Ln CR & -1.00 & $+0.12^{\mathrm{B}}( \pm 0.031)$ & 37 & 0.31 & 3.3 \\
\hline & & Ln NBR & -4.47 & $+0.12^{\mathrm{C}}( \pm 0.016)$ & 43 & 0.75 & 3.3 \\
\hline & & Ln NCR & -3.37 & $+0.07^{\mathrm{D}}( \pm 0.031)$ & 37 & 0.12 & 2.0 \\
\hline \multicolumn{2}{|l|}{ Transect } & Ln BR & & n.s. & 7 & & \\
\hline \multirow[t]{3}{*}{ Nov 2001} & \multirow[t]{3}{*}{$21-32$} & Ln CR & +0.81 & $+0.09^{\mathrm{B}}( \pm 0.007)$ & 7 & 0.98 & 2.5 \\
\hline & & Ln NBR & -4.27 & $+0.11^{\mathrm{C}}( \pm 0.019)$ & 7 & 0.86 & 3.0 \\
\hline & & Ln NCR & -2.12 & $+0.03( \pm 0.012)$ & 7 & 0.60 & 1.3 \\
\hline \multicolumn{2}{|l|}{ Transect } & Ln BR & & n.s. & 7 & & \\
\hline \multirow[t]{3}{*}{ May 2002} & \multirow[t]{3}{*}{$23-35$} & Ln CR & +1.03 & $+0.09^{\mathrm{B}}( \pm 0.007)$ & 7 & 0.97 & 2.5 \\
\hline & & Ln NBR & -3.58 & $+0.09^{\mathrm{C}}( \pm 0.010)$ & 7 & 0.94 & 2.5 \\
\hline & & Ln NCR & -4.03 & $+0.10^{\mathrm{D}}( \pm 0.016)$ & 7 & 0.87 & 2.7 \\
\hline \multirow{4}{*}{$\begin{array}{l}\text { Transect } \\
\text { Jun } 2002\end{array}$} & \multirow{4}{*}{$29-37$} & Ln BR & & n.s. & 7 & & \\
\hline & & Ln CR & +1.67 & $+0.06( \pm 0.017)$ & 7 & 0.71 & 1.8 \\
\hline & & Ln NBR & -4.42 & $+0.12^{\mathrm{C}}( \pm 0.015)$ & 7 & 0.92 & 3.3 \\
\hline & & Ln NCR & & n.s. & 7 & & \\
\hline \multirow{4}{*}{$\begin{array}{l}\text { Temp. manipulation }{ }^{\mathrm{a}} \\
\text { Dec } 2001\end{array}$} & \multirow[t]{4}{*}{$21-37$} & Ln BR & -0.23 & $+0.10^{\mathrm{A}}( \pm 0.027)$ & 12 & 0.86 & 2.7 \\
\hline & & Ln CR & +0.43 & $+0.10^{\mathrm{B}}( \pm 0.005)$ & 12 & 0.99 & 2.7 \\
\hline & & Ln NBR & -4.01 & $+0.10^{\mathrm{C}}( \pm 0.026)$ & 12 & 0.88 & 2.7 \\
\hline & & Ln NCR & -4.12 & $+0.10^{\mathrm{D}}( \pm 0.004)$ & 12 & 0.99 & 2.7 \\
\hline \multirow{4}{*}{$\begin{array}{l}\text { Temp. manipulation }{ }^{\mathrm{a}} \\
\quad \text { Mar } 2002\end{array}$} & \multirow[t]{4}{*}{$21-37$} & Ln BR & -0.55 & $+0.11^{\mathrm{A}}( \pm 0.019)$ & 12 & 0.95 & 3.0 \\
\hline & & Ln CR & +0.45 & $+0.11^{\mathrm{B}}( \pm 0.010)$ & 12 & 0.98 & 3.0 \\
\hline & & Ln NBR & -4.31 & $+0.12^{\mathrm{C}}( \pm 0.018)$ & 12 & 0.95 & 3.3 \\
\hline & & Ln NCR & -4.33 & $+0.11^{\mathrm{D}}( \pm 0.010)$ & 12 & 0.98 & 3.0 \\
\hline \multirow{4}{*}{$\begin{array}{l}\text { Temp. manipulation } \\
\text { Aug } 2002\end{array}$} & \multirow[t]{4}{*}{$20-38$} & Ln BR & -0.41 & $+0.11^{\mathrm{A}}( \pm 0.020)$ & 12 & 0.94 & 3.0 \\
\hline & & Ln CR & +0.14 & $+0.12^{\mathrm{B}}( \pm 0.018)$ & 12 & 0.96 & 3.3 \\
\hline & & Ln NBR & -4.22 & $+0.11^{\mathrm{C}}( \pm 0.019)$ & 12 & 0.94 & 3.0 \\
\hline & & Ln NCR & -4.86 & $+0.12^{\mathrm{D}}( \pm 0.018)$ & 12 & 0.96 & 3.3 \\
\hline
\end{tabular}

the transect studies, which showed no correlation with temperature. Note that the slopes of $\ln$ BR vs. T curves of the inlet $(0.12 \pm 0.008)$ and outlet $(0.11 \pm$ 0.009) were almost identical (ANCOVA, p > 0.01, Table 3). But the intercept of the outlet $(-1.83)$ was smaller than that of the inlet $(-0.76$, ANCOVA, $\mathrm{p}<0.01$, Table 3). After normalizing BR with BB, the slope of $\ln$ NBR vs. T of the inlet $(0.13 \pm 0.007)$ was not different from that of the outlet $(0.12 \pm 0.016$, ANCOVA, $p>0.01$ ), and the difference between their intercepts was significantly reduced (i.e. -4.9 vs. -4.5). These phenomena were also applicable to the relationships of $\ln \mathrm{CR}$ (and $\ln \mathrm{NCR}$ ) vs. T. However, the temperature response of NCR was insignificant in the June transect study. The $Q_{10}$ values for $B R, C R$, NBR and NCR in the field studies ranged from 1.3 to 4.5 (Table 3).

\section{DISCUSSION AND CONCLUSIONS}

\section{The inlet system}

We observed extremely high DOC concentrations, with an annual average of $>25 \mathrm{~g} \mathrm{C} \mathrm{m}^{-3}$. There are neither rivers nor a dense population in the vicinity of the TNP-II. DOC concentrations were always high, without any trend with seasonal $\mathrm{T}$ (and/or S), indicating a constant but unknown DOC source. The TNP-II started to operate in 1980, and foaming (the formation of white bubbles at the surface water) has been frequently reported at the inlet and outlet since then (Shiah et al. 2005). One of the possible DOC sources may be the abandon dumping site adjacent to the TNP-II. Subsequent investigation has indicated that DOC concentrations have decreased to a range of 1.4 
to $6.4 \mu \mathrm{mg} \mathrm{C} \mathrm{m} \mathrm{m}^{-3}$ since August 2003 (F.-K. Shiah unpubl. data). Despite the high concentrations of DOC, the rate parameters (Tables $1 \& 2$ ) recorded at the inlet were not aberrant when compared with those of other estuarine and coastal systems. For example, the seasonal maximal CR ( 600 $\mathrm{mg} \mathrm{C} \mathrm{m}^{-3}$ $\mathrm{d}^{-1}$, Smith \& Kemp 1995) and BP ( 160 mg C m${ }^{-3} \mathrm{~d}^{-1}$, Shiah \& Ducklow 1995) in the Chesapeake Bay area were, in fact, higher than ours, although the maximal DOC values recorded in the bay area $\left(9.6 \mathrm{mg} \mathrm{C} \mathrm{m}^{-3}\right.$, Ducklow et al. 1998) were much lower than ours.

Many studies have suggested that smaller (size $<300 \mu \mathrm{m}$ ) plankton are more important than larger plankton in partitioning $\mathrm{CR}$, and that BR alone might constitute $>50 \%$ of the CR in many systems (Hopkinson et al. 1989, Blight et al. 1995, del Giorgio et al. 1997, Duarte \& Agusti 1998, Smith \& Kemp 2001). Since bacteria are one of the components of CR, their respiration can never exceed the CR. In field observations, there were only 4 data with BR/CR $>1.0$, while the other 134 data were $<0.76$ (Fig. 2E). The grand average $\mathrm{BR} / \mathrm{CR}$ ratio was $0.41 \pm 0.25$ at the inlet. We observed that the ratios of BR/CR decreased exponentially with increasing $\mathrm{CR}$ in the inlet, outlet and transect studies (Table 4, Fig. 5). Note that 4 out of 5 cases showed similar slopes and intercepts; the only exception was the transect study performed in June 2002, in which the intercept and slope were 2-fold of the other cases. To date, we have not found any similar report of this. In the Chesapeake Bay, Smith \& Kemp (2001) showed that the $C R$ of the $<3 \mu$ m size fraction (i.e. $R_{3}$ ) changed positively and linearly with that of the total CR (i.e. $\mathrm{R}_{\mathrm{T}}$ ), with a slope value of 0.76 (e.g. their Fig. 2b). This meant that the $\mathrm{R}_{3} / \mathrm{R}_{\mathrm{T}}$ ratios were constant over $\mathrm{R}_{\mathrm{T}}$. In addition to bacteria, their $<3 \mu \mathrm{m}$ size fraction may contain many non-bacterial plankton, including protozoans such as flagellates and small ciliates, etc. Unfortunately, Smith \& Kemp (2001) did not measure BR in their research, which makes it impossible to know that whether the BR/CR vs. CR relationship observed in this study would also hold for the Chesapeake Bay.

In a parallel zooplankton study, J.-L. Chung et al. (unpubl. data) noted that the abundance of micro-zooplankton (size $<300 \mu \mathrm{m}$ ) and their grazing on chl $a$ increased with seasonal temperature. We suspect that the non-bacterial fraction, which includes micro-zooplankton, ciliates and flagellates, might contribute more to CR during high CR (and warm) periods. This reflects the results of Cole et al. (2000), suggesting that the change in the food-web structure could alter the dynamics of heterotrophic processes and, thus, the respiration ratio.
Table 4. Statistics for the linear regression of rate ratios of bacterial vs. community respiration (independent variable) on natural log-transformed community respiration (ANCOVA). Slopes sharing the same capital superscript letter were not considered different from each other at $p=0.01$ level (SE: standard error; $n$ : sampling size; $\mathrm{R}^{2}$ : coefficient of determination)

\begin{tabular}{|lccrc|}
\hline Data source & Intercept & Slope $( \pm$ SE $)$ & $n$ & $\mathrm{R}^{2}$ \\
\hline Weekly inlet & 122 & $-25.7^{\mathrm{A}}( \pm 3.6)$ & 78 & 0.85 \\
Weekly outlet & 134 & $-29.9^{\mathrm{A}}( \pm 4.6)$ & 37 & 0.78 \\
Transect, Nov 2001 & 113 & $-28.3^{\mathrm{A}}( \pm 6.0)$ & 7 & 0.98 \\
Transect, May 2002 & 113 & $-24.9^{\mathrm{A}}( \pm 3.7)$ & 7 & 0.97 \\
Transect, Jun 2002 & 251 & $-59.3( \pm 17.4)$ & 7 & 0.71 \\
\hline
\end{tabular}

Our finding of this inverse BR/CR vs. CR relationship indicates that the proportion of $\mathrm{O}_{2}$ (and organic carbon) consumed by bacteria might become less significant during either higher $\mathrm{CR}$ or warmer season or both. However, it must be noted that this finding was derived from systems with aberrantly high DOC and temperature; its applicability to other coastal ecosystems might be still questionable.

Pomeroy et al. (1995) suggested that respiration of phytoplankton (PR) constituted a low fraction of total CR. Grande et al. (1989) indicated that PR was about $20 \%$ of PP. J.-L. Chung et al. (unpubl. data) showed that PR in the study area, on average, constituted $11 \%$ of the total CR. This leaves, at most, $50 \%$ of the total CR to protozoans (flagellates and ciliates) and other plankton with sizes $<300 \mu \mathrm{m}$. Robinson et al. (2002) suggested that protozoans alone might constitute 21 to $50 \%$ of the total CR in the Atlantic. Our highest estimate of non-bacterial respiration in the $<300 \mu \mathrm{m}$ fraction in a coastal system with high organic loading is within the reported range of protozoan contribution to $\mathrm{CR}$.

Temperature and biomass of living biota have been considered the 2 most important factors in determining the variation of CR in the field (Hopkinson et al. 1989,

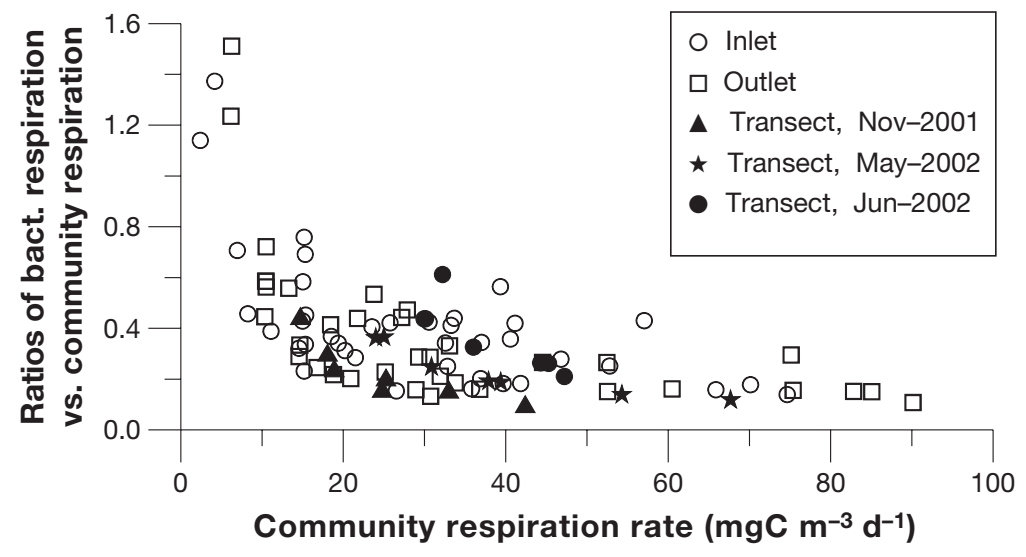

Fig. 5. Scatter plots for the ratios of bacteria:community respiration vs. community respiration. Statistical analysis for each survey was shown in Table 4 
Sampou \& Kemp 1994, Blight et al. 1995). In a review paper, Lomas et al. (2002) showed that the $Q_{10}$ for CR in coastal and estuarine ecosystems varied from 1.2 to 9.3. Our values ranged from 3.3 to 3.4 (Table 3 ). In addition to $\mathrm{T}, \mathrm{CR}$ data were also positively correlated with chl $a$ and POC (Table 1). Note that chl a was one of the components of POC. We did not perform multiple regression to analyze the combined effects of $\mathrm{T}$ and POC on $\mathrm{CR}$, due to the auto-correlation between $\mathrm{T}$ and POC (Table 1, Edwards 1985). One way to overcome this problem is to do a linear regression of T on NCR by assuming that the collected POC samples are composed of living organisms only. This method is risky, since microscopic examination showed an abundance of amorphorous debris in the POC samples, particularly at the outlet station. This was the main reason why the temperature response of $\ln \mathrm{NCR}$ at the inlet and outlet showed low coefficients of determination $\left(\mathrm{R}^{2}<0.35\right)$. On the other hand, POC-normalized CR was feasible in the 3 temperature-manipulation experiments, since the same stock of seawater was used in each experiment. There, temperature responses of NCR were significant, with $\mathrm{R}^{2}$ values >0.96 (Table 3).

\section{The outlet and the plume systems}

All organisms are killed via the reactor cooling processes. Before reaching the outlet, this 'boiled', coolant water is mixed with normal seawater (from the inlet) in a $\sim 3 \mathrm{~km}$ pipeline. The discharged warm water is then further mixed with ambient seawater within the plume. The observed microbial activity within the outlet plume is a result of mixing dead organisms with live ones, thus an activity gradient is set up within the plume. This is supported by results showing that the chl $a$ and BB values at the outlet were $<40 \%$ of those at the inlet. And, these 2 variables increased seaward within the warm plume as it cooled (Fig. 3B,D). What surprised us was that the temperature responses of CR in these 2 heavily impacted systems were quite similar to those of the inlet and temperature-manipulation experiments (Table 3). This suggests that heterotrophic processes in this 'anthropogenically warm' system can still proceed with the same rates as those in a normal system. We found that at the outlet and the plume, NBR could still increase up to $>35^{\circ} \mathrm{C}$ (Table 3 ) without any trend of thermal inhibition, until temperatures surpassed $40^{\circ} \mathrm{C}$ (Fig. 4D).

Thermal stress might act on autotrophs living in the outlet and the warm plume. Servias \& Billen (1989) showed that bacteria could tolerate higher temperatures than phytoplankton near the Muse power plant. Near the Hadong power station (Korea), Choi et al. (2002) demonstrated that a temperature of $40^{\circ} \mathrm{C}$ in- hibited BP by 23 to $69 \%$, but had no effect on heterotrophic nanoflagellates. This indicated that larger heterotrophs might endure a higher magnitude of thermal stress than phytoplankton and bacteria. With data taken from temperature-manipulation experiments performed in the same area, Shiah et al. (2005) showed that the reduction of chl a normalized maximal primary production (i.e. $P^{\mathrm{B}}{ }_{\max }$ ) and that the initial slope occurred at temperatures $>30^{\circ} \mathrm{C}$, while our NBR and NCR still maintained high values at a temperature $>35^{\circ} \mathrm{C}$ (Fig. 4A,B). We suspected that the differential thermal tolerance between bacteria and other larger organisms might be one of the potential causes resulting in the inverse BR/CR ratio vs. $\mathrm{CR}$ (and $\mathrm{T}$ ) relationship observed in the outlet and plume.

\section{Implications for organic carbon cycling}

The significant temperature responses of the respiration parameters during the field survey and temperature-manipulation experiments indicate that the growth of plankton was seldom limited by bottom-up (i.e. substrate supply) processes. The $Q_{10}$ value for BR recorded in the field study and the temperaturemanipulation experiments $\left(Q_{10}=2.7\right.$ to 3.3 , Table 3$)$ fell within the reported range for estuarine systems $\left(Q_{10}=1.2\right.$ to 4.0 , Lomas et al. 2002, and citations therein). In the Chesapeake Bay (Shiah \& Ducklow 1995) and on the shelf of the East China Sea (Shiah et al. 2000), the bacterial growth rates increased with temperature and reached maxima at ca. 20 to $25^{\circ} \mathrm{C}$. Our data, on the other hand, showed that maximal NBR (and growth rate, too) occurred at temperatures of $>30^{\circ} \mathrm{C}$. This might be due to a much more abundant supply (or higher concentrations) of labile DOC in the study area, which led to the substrate limitations on bacterial growth occurring at higher temperatures. In a parallel inlet study, Shiah et al. (2005) demonstrated that the addition of zooplankton extract (final conc., $\sim 24 \mathrm{~g} \mathrm{C} \mathrm{m}^{-3}$ ) did not enhance bacterial growth. Their experiments suggested that in situ DOC from the study area was as labile as the dissolved organic matter from animal tissue. This provides another example of substrate-temperature interactions on bacterial growth (Pomeroy \& Wiebe 2001) and, thus, respiration.

Our results might have some implications for future carbon cycling predictions. As one may note, global warming and increasing anthropogenic activities are 2 inevitable trends. Their potential impacts on the roles coastal ecosystems play as a source or sink of $\mathrm{CO}_{2}$ have been of great concern (Smith \& Hollibaugh 1993, del Giorgio et al. 1997, Duarte \& Agusti 1998, Williams 1998). Our study provides evidence suggesting heterotrophic microorganisms in many coastal systems are 
capable of adapting to the rising temperatures and of continuing to respire organic carbon, as long as organic availability is high. It should be noted that our deduction might be immature, since global warming is a slow, gradual temperature-change phenomenon, in which microbial processes are regulated over longer temporal scales, while this study only offered evidence showing heterotrophs' immediate temperature responses in a high DOC environment.

In summary, the study system has been subjected to high loads of dissolved organic matter and high temperature (the outlet and plume), but the standing stocks and rates of many heterotrophic organisms behaved pretty much the same as in other ecosystems that receive less organic input. This suggests that a system itself might have a capacity for self-adjustment by changing its food-web structure, although most of this theory is speculative. The negative relationship between $\mathrm{BR} / \mathrm{CR}$ and $\mathrm{CR}$, as revealed by our results, indicates that non-bacterial organisms might be more important than bacteria in consuming organic carbon during warmer seasons, when CR levels are high. However, this phenomenon calls for more comparisons to ascertain its applicability to other systems. Positive temperature responses of heterotrophic processes are to be expected in systems where organic matter supply rates, either in the dissolved or particulate phase, exceed plankton growth requirements. Finally, similar heterotrophic Arrhenius-type expressions observed in systems with contrasting temperature regimes do suggest that the biogenic emission rate of $\mathrm{CO}_{2}$ in most, if not all, coastal systems might keep increasing when faced with a sudden temperature rise, as long as anthropogenic organic loadings are high.

Acknowledgements. This research was supported by the Taiwan Power Plant, Grant No. TPC-048-90-3505-07. NCOR Contribution Paper No. 00085. Res Ctr Biodiversity-Academia Sinicia contribution paper. Valuable comments from 3 anonymous reviewers are deeply appreciated.

\section{LITERATURE CITED}

Bauer JE, Druffel ERM (1998) Ocean margins as a significant source of organic matter to the deep open ocean. Nature 392:482-485

Blight SP, Bentley TL, Lefevre D, Robinson C, Rodrigues R, Rowlands J, Williams PJ LeB (1995) Phasing of autotrophic and heterotrophic plankton metabolism in a temperate coastal ecosystem. Mar Ecol Prog Ser 128:61-75

Choi DH, Park JS, Hwang CY, Huh SH, Cho BC (2002) Effects of thermal effluents from a power station on bacterial and heterotrophic nanoflagellates in coastal waters. Mar Ecol Prog Ser 229:1-10

Cole JJ, Pace ML, Carpenter SR, Kitchell JF (2000) Persistence of net heterotrophy in lakes during nutrient addition and food web manipulations. Limnol Oceanogr 45(8):1718-1730
Dai CF (1999) Reef check and coral bleaching. Bull APEC MRC 1(2):16-18

del Giorgio PA, Cole JJ, Cimbleris A (1997) Respiration rates in bacteria exceed phytoplankton production in unproductive aquatic systems. Nature 385:148-151

Duarte CM, Agusti S (1998) The $\mathrm{CO}_{2}$ balance of unproductive aquatic ecosystems. Science 281:234-236

Ducklow HW, Carlson C (1992) Oceanic bacterial production. In: Marshall KC (ed) Advances in microbial ecology. Plenum Press, New York, p 113-181

Ducklow HW, Schultz GL, Raymond P, Bauer J, Shiah FK (1998) Bacterial dynamics in large and small estuaries. In: Bell CR, Brylinsky M, Johnson-Green P (eds) Microbial ecology of estuaries. Atlantic Canada Society for Microbial Ecology, Halifax, NS, p 105-111

Edwards AL (1985) Multiple regression and analysis of variance and covariance. W. H. Freeman, New York

Fuhrman JA, Azam F (1982) Thymidine incorporation as a measure of heterotrophic bacterioplankton production in marine surface waters: evaluation and field results. Mar Biol 66:109-120

Gong GC, Liu KK, Pai SJ (1995) Prediction of nitrate concentration from two end member mixings in the southern East China Sea. Deep-Sea Res I 15:827-842

Grande KD, Williams PJ LeB, Marra J, Purdie DA, Heinemann K, Eppley RW, Bender M (1989) Primary production in the North Pacific gyre: a comparison of rates determined by the ${ }^{14} \mathrm{C}, \mathrm{O}_{2}$ concentration and ${ }^{18} \mathrm{O}$ methods. Deep-Sea Res I 36:1621-1634

Hobbie JE, Daley RJ, Jasper S (1977) Use of nuclepore filters for counting bacteria by fluorescence microscopy. Appl Environ Microbiol 33(5):1225-1228

Hopkinson CS, Sherr B, Wiebe WJ (1989) Size fractionate metabolism of coastal microbial plankton. Mar Ecol Prog Ser 51:155-166

Hung TC, Huang CC, Shao KT (1998) Ecological survey of coastal water adjacent to nuclear power plants in Taiwan. Chem Ecol 1:129-142

Lancelot C, Billen G (1984) Activity of heterotrophic bacteria and its coupling to primary production during the spring phytoplankton bloom in the southern bight of the North Sea. Limnol Oceanogr 29:721-730

Lomas MW, Glibert PG, Shiah FK, Smith E (2002) Microbial processes and temperature in Chesapeake Bay: current relationships and potential impacts of regional warming. Global Change Biol 8:51-70

Pai SC, Gong GC, Liu KK (1993) Determination of dissolved oxygen by direct spectrophotometry of total iodine. Mar Chem 41:343-351

Parsons TR, Miata Y, Lalli M (1984) A manual of chemical and biological methods for seawater analysis. Pergamon, New York

Pomeroy LR (1974) The ocean's foodweb, a changing paradigm. BioScience 24(7):499-504

Pomeroy LR, Wiebe WJ (2001) Temperature and substrates as interactive limiting factors for marine heterotrophic bacteria. Aquat Microb Ecol 23:187-204

Pomeroy LR, Sheldon JE, Sheldon Jr WM, Peters F (1995) Limits to growth and respiration of bacterioplankton in the Gulf of Mexico. Mar Ecol Prog Ser 117:259-268

Redfield AC, Ketchum BH, Richards FA (1963) The influence of organisms on the composition of seawater. In: Hill MN (ed) The sea, Vol 2. Inter-Science, New York, p $26-77$

Rivkin RB, Legendre L (2001) Biogenic carbon cycling in the upper ocean: effects of microbial respiration. Science 291: 2398-2400 
Robinson C, Serret P, Tilstone G, Teira E, Zubkov MV, Rees AP, Woodward EM (2002) Plankton respiration in the eastern Atlantic Ocean. Deep-Sea Res I 49:787-813

Sampou P, Kemp WM (1994) Factors regulating plankton community respiration in Chesapeake Bay. Mar Ecol Prog Ser 110:249-258

Servais P, Billen G (1989) Impact of a nuclear power plant on primary production and bacterial heterotrophic activity in the River Meuse at Tihange (Belgium). Arch Hydrobiol 114(3):415-429

Shiah FK, Ducklow HW (1995) Multi-scale variability in bacterioplankton abundance, production and specific growth rate in a temperate salt marsh tidal creek. Limnol Oceanogr 40(1):55-66

Shiah FK, Gong GC, Chen TY, Chen CC (2000) Temperature dependence of bacterial specific growth rates on the continental shelf of the East China Sea and its potential application in estimating bacterial production. Aquat Microb Ecol 22:155-162

Shiah FK, Gong GC, Chen CC (2003) Seasonal and spatial variation of bacterial production in the continental shelf of the East China Sea: possible controlling mechanisms and

Editorial responsibility: Jennifer Purcell (Contributing Editor), Anacortes, Washington, USA potential roles in carbon cycling. Deep-Sea Res II 50: 1295-1309

Shiah FK, Tue YY, Tsai HS, Kao SJ, Jan S (2005) A case study of system and planktonic responses in a subtropical warm plume receiving thermal effluents from a power plant. Terr Atmos Ocean Sci 16(2):513-528

Smith EM, Kemp WM (1995) Seasonal and regional variations in plankton community production and respiration for Chesapeake Bay. Mar Ecol Prog Ser 116:217-231

Smith EM, Kemp WM (2001) Size structure and the production/respiration balance in a coastal plankton community. Limnol Oceanogr 46:473-485

Smith EM, Kemp WM (2003) Planktonic and bacterial respiration along an estuarine gradient: responses to carbon and nutrient enrichment. Aquat Microb Ecol 30:251-261

Smith SV, Hollibaugh JT (1993) Coastal metabolism and the oceanic carbon balance. Rev Geophys 31:75-93

Toolan T (2001) Coulometric carbon-based respiration rates and estimates of bacterioplankton growth efficiencies in Massachusetts Bay. Limnol Oceanogr 46(6):1298-1309

Williams PJLeB (1998) The balance of plankton respiration and photosynthesis in the open oceans. Nature 394:55-57

Submitted: March 16, 2005; Accepted: August 19, 2005

Proofs received from author(s): January 25, 2006 